\title{
СТРАТИГРАФИЯ АРЕНИГСКИХ И ЛЛАНВИРНСКИХ ОТЛОЖЕНИЙ (ЛАТОРПСКИЙ-ЛАСНАМЯГИСКИИ ГОРИЗОНТЫ) ВОСТОЧНОЙ ЛИТВЫ И СЕВЕРО-ЗАПАДНОЙ БЕЛОРУССИИ
}

Сероцветные терригенно-карбонатные отложения нижнего и низов среднего ордовика Восточной Литвы и Северо-Западной Белоруссии представляют собой образования юго-восточной краевой части шельфа ордовикскопо эпиконтинентального Балтийского бассейна (рис. 1). Они развиты в пределах северо-восточного склона Мазурско-Белорусской антеклизы и залегают на глубине от -400 до +76 м. На бо́льшей части территории они перекрываются отложениями ухакуского горизонта, в северо-восточной части - отложениями девона со стратиграфическим перерывом, в юго-восточной - сморгонокой свитой оандуского горизонта среднего ордовика. Мощность стратиграфически полных разрезов колеблется от 11 до 19,2, а мощность сокращенных в связи с проявлением постседиментационных стратиграфических перерывов от 1,7 до 10 м.

Многими авторами разработаны стратиграфия расоматриваемых отложений и местная стратиграфическая схема (Пашкевичюс, 1960, 1973; Саладжюс, 1970; Сидаравичене, 1972; Решения..., 1978; Пушкин и др., 1981; Лашков и др., 1983). В настоящее время уточнены границы и объемы горизонтов, проведена корреляция с отложениями соответствующей структурно-фациальной зоны в Северной Эстонии. Установлено сходство последних с отложениями Юго-Восточной Прибалтики. В Литовоко-Белорусской зоне (рис. 1) выше волховского горизонта выделяются в разрезе новые самостоятельные местные стратиграфические подразделения - свиты. В данной статье рассмотрен их стратотип - разрез скв. Твярячюс 336 (Литовская ССР, Игналинский район), обобщена главная, имеющаяся з настоящее время биостратиграфическая информация об отложениях аренигското и лланвирнского возрастов еще нескольких разрезов. Литологическую характеристику разрезов составили Е. Лашков и С. Мяги. Трилобиты и брахиоподы изучал И. Пашкевичюс, часть брахиопод - В. Пушкин и С. Мяги, мшанки - В. Пушкин, цефалоподы - В. Саладжюс, микрофауну конодонтов - С. Мяги, остракоды - Н. Сидаравичене и С. Сауленене.

\section{Леэтсеская свита}

Леэтсеская свита терригенно-карбонатных пород в Северной Эстонии (Рымусокс, 1956; Решения..., 1978), в скв. Твярячюс, вскрыта на глубине $331,2-330,8$ м и представлена серо-зеленым разнозернистым глауконитово-кварцевым песчаником с тлинисто-карбонатным цементом базального и порового типа, В кровле отмечается неровная поверх- 


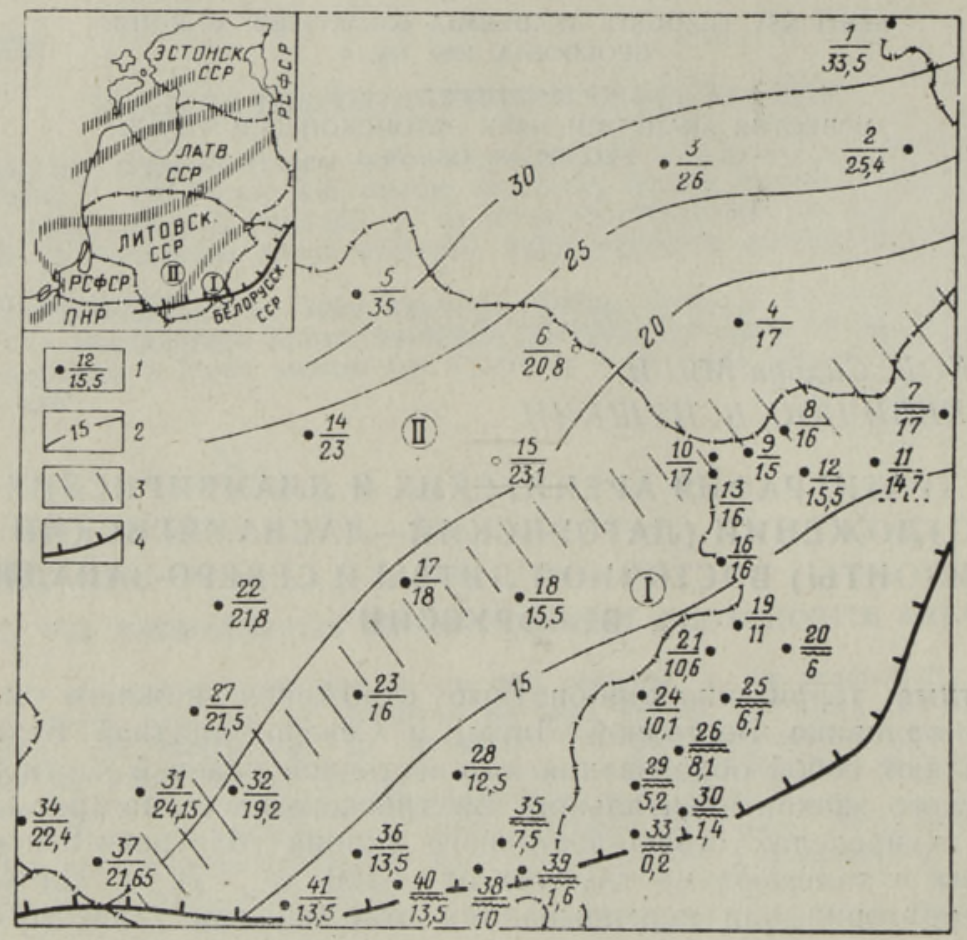

Рис. 11. Карта мощностей и структурно-фациального районирования отложений аренига и лланвирна юго-восточной части Балтийского бассейна. 1 - скважнна: в числителе - номер скважнны, в знаменателе мощность отложений (пунктирный знак под цифрой обозначает, что отложения скважины вскрыты не полностью, волнистый знак над цифрой указывает, что рассматриваемые отложения перекрываются с постседиментационным стратиграфическим перерывом); 2 - изопахиты; 3 - границы фациальных зон; 4 - южная граница распространения отложений. Структурно-фациальные зоны: I - Литовско-Белорусская, II - Литовско-Латвийская. Скважины: 1 - Балтинава 17; 2 Лудза 15; 3 - Аташиена 9; 4 - Вышки 25; 5 - Ликенай 396; 6 - Буткунай 241; 7 - Верхнедвинск (Дрисса); 8 - Вангишки $205 ; 9$ - Межаны 210; 10 - Друкщяй $324 ; 11-\Pi 2 ; 12$ Ричаны 209; 13 - Заборье 8; 14 - Стачюнай 8; 15 - Сведасай $252 ; 16$ - Твярячюс $336 ; 17$ - Укмерге $10 ; 18$ - Ляляй $282 ; 19$ - Оцковичи $5 ; 20$ - Лотва $6 ; 21$ - Полхуны $4 ; 22$ Лядай $179 ; 23$ - Паукщяй $192 ; 24$ - Буйки $7 ; 25$ - Купа 1; 26 - Андреевцы 8; 27 - Вирбалншкес 434; 28 - Яченнс 299; 29 - Ольгиняны 068; 30 - Смолярная 035; 31 - Саснава 6; 32 - Пренай 3 ; 33 - Журланы 033; 34 - Паявонис 34; 35 Вилькишкяй $68 ; 36$ - Таученис $49 ; 37$ - Кальвария $2 ; 38$ Скердзимай $70 ; 39$ - Акмянине $71 \mathrm{a} ; 40$ - Валькининкай 404; 41 - Илгай 54.

ность перерыва, пропитанная гидроокислами железа. Конодонтовая зона Oepikodus evae (рис. 2) указывает.на позднелаторпский (биллингенский) возраст отложений (Lindström, 1971). По составу и возрасту отложения соответствуют мяэкюлаской пачке верхов леэтсеской свиты стратотипического района (Мяги, Вийра, 1976).

В других скважинах рассматриваемого района леэтсеская свита также представлена разнозернистым кварцево-глауконитовым и глауконитовым (в разной степени сцементированным) песчаниками с прослоями глинистого алевролита, глины, мергеля и доломита, содержащими глауконит. В Юго-Восточной Литве (скв. Инклеришкес, Таученис) в основании свиты (до 10 см) имеются конгломераты, состоящие 

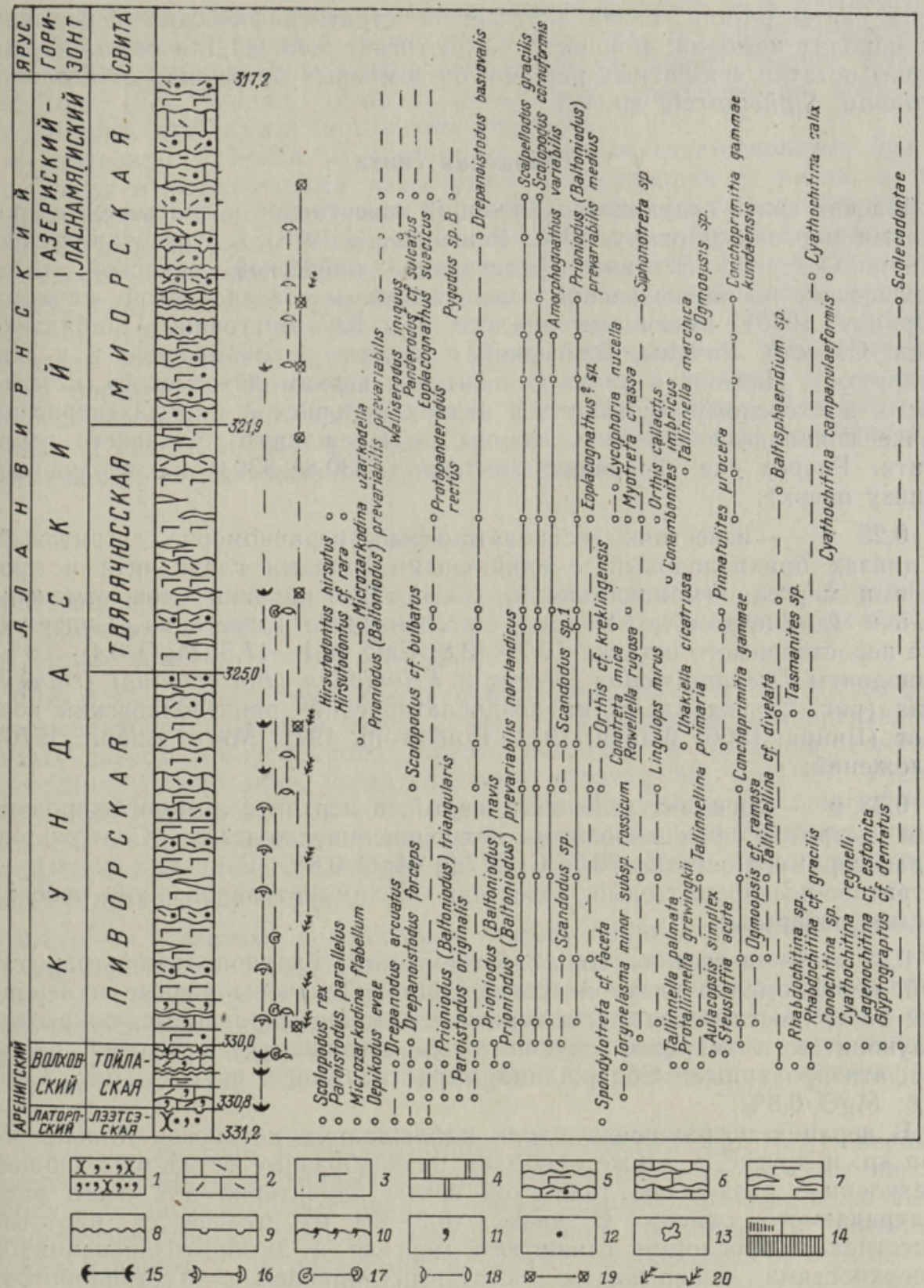

Рис. 2. Стратотипический разрез скв. Твярячюс. $I$ - песчаники глауконитовые и кварцево-глауконитовые; 2 - известняки органогенно-детритовые; 3 - мергели; 4 - доломиты; 5 - слоистость волнисто-полосчатая; 6 - линзовндные и неправильные формы включения мергелей среди известняков; 7 - стяжения известняков среди мергелей; 8 - стратиграфические перерывы; 9 - седиментационные поверхности перерыва, пропитанные гидроокислами железа; 10 - неровные поверхности седиментационных перерывов, покрытые глауконитом; 11 глауконит; 12 - оолиты и псевдооолиты гидроокислов железа; 13 - каверны; 14 - красноцветные прослои и полоски; 15-20 характерный органогенный компонент в породах: брахноподы (15), трилобиты (16), мнкрогастроподы (17), остракоды (18), иглокожие (19), граптолиты (20).

из хорошо окатанных галек кварцевого песчаника размером до 5 см, сцементированных кварцево-тлауконитовым материалом. Нижняя гра- 
ница свиты резкая; свита залегает со стратиграфическим перерывом на породах кембрия; мощность ее достигает 0,45 м. Для свиты характерны остатки фосфатных раковин беззамковых брахиопод Schizambon esthonia, Siphonotreta sp. и т. д.

\section{Тойлаская свита}

Тойлаокая свита глауконитсодержащих известняков и доломитов с прослоями мергеля (Орвику, 1958; Решения..., 1978) в стратотипическом районе Северной Әстонии представлена пяйтеской, сакаской, телиныммеской, кюннапыхьяской, кальвиской и лахепераской пачками (Орвику, 1960), имеющими аналоги и в Юго-Восточной Прибалтике (скв. Струсто, Ричаны, Вангискяй и другие, видоизмененно и в скв. Твярячюс). Пяйтеская пачка относится к верхам латорпского, остальные к волховскому горизонту; в верхах кальвиской и в лахепераской пачке появляются элементы фауны вышележащего кундаского горизонта. Разрез скв. Твярячюс (интервал $330,8-330,0$ м) следующий (снизу вверх):

1) 0,25 м - известняк зеленовато-серый, неравномерно детритовый, в линзах брахиоподовый, с единичными зернами глауконита и прослоями мергеля (мощностью до 1 см). В основании слоя отмечены гальки (диаметром до 1,1 см) ожелезненного известняка. Содержание нерастворимого остатка 10,7-13,8; CaO 46,1-47,5; $\mathrm{MgO} 0,4-0,8 \%$. Конодонты Drepanoistodus forceps и Prioniodus (Baltoniodus) triangularis (рис. 2) указывают на позднелаторпский-ранневолховский возраст (Вийра, 1966; Wamel, 1974; Lindström, 1971; Мяги, Вийра, 1976) отложений;

2) 0,33 м - аргиллит зеленовато-серый, в верхах с лимонитизированным детритом (псевдооолиты гидроокислов железа). Содержание нерастворимого остатка 76,$7 ; \mathrm{CaO} 7,2 ; \mathrm{MgO} 0,8 \%$. В кровле (3 см) детритово-псевдооолитовый известняк с лимонитизированной поверхностью перерыва;

3) 0,22 м - известняк серый биоморфный, брахиоподово-остракодовый, неравномерно глауконитсодержащий. Отмечены ровные и неровные поверхности перерыва, в середине лимонитизированные, покрытые глауконитом и кварцево-глауконитовым материалом, в верхней части фосфатизированные. Содержание нерастворимого остатка 6,$5 ; \mathrm{CaO}$ 46,6; $\mathrm{MgO} 0,8 \%$.

В верхних пограничных слоях наблюдаются хитинозои Rhabdochitina sp. и другие, а также в обилии разнообразные остракоды. Общее трехчленное разделение тойлаской свиты характерно для всего рассматриваемого района. В низах $(0,2-0,4$ м) отмечается плотный известняк с прослоями глинистого мергеля и лимонитизированными поверхностями перерыва, с остатками брахиопод и трилобитов. В северо-западной части района породы пестро- и красноцветные, нередко доломитизированные; мощность комплекса увеличивается. На юго-востоке, ближе к прибрежной фации, нет резкого перехода к подстилающей леэтсеской свите: в основании комплекса отмечается чередование слоев кварцево-глауконитового песчаника с прослоями известняка и доломита. Возраст нижнего комплекса позднелаторпский-ранневолховский.

В средней части свиты $(0,3-1,1$ м) чередуются слои светло-серого мергеля, глины и комковатого тлинистого известняка. Глауконит практически отсутствует или отмечается спорадически. Послойно породы брахиоподово-биоморфные. В разрезе Струсто, в кровле слоя, наблю даются ярко-красные пятна, характерные для верхов лимбатового известняка (bloody layers) на о, Эланде. В разрезе Твярячюс мало- 
мощная средняя часть свиты осталась неопробованной, но в соответствующей глинистой средней части комплекса скв. Друкщяй отмечена характерная для середины волховского горизонта (B $\mathrm{B}_{\text {II }}$ ) (Вийра, 1966; Lindström, 1971; Wamel, 1974; Löfgren, 1978) конодонтовая зона с Triangulodus brevibasis и Paroistodus originalis.

Верхи свиты $(0,1-0,8$ м) состоят из плотных толстослоистых брахиоподовых и остракодовых известняков, содержащих в низах и в средней части многочисленные (5-10\%) мелкие зерна глауконита и лимонитизированные, в верхней - фиолетовые фосфатизированные поверхности перерыва. Первый снизу слой охарактеризованной толщи соответствует, очевидно, армонской пачке драйсейкской свиты, расположенной западнее (Решения..., 1978; Лашков и др., 1983). В верхней части тойлаской свиты в скв. Купа, Верхнедвинск, Оцковичи и других определены Ranorthis carinata, Paurorthis minima, P. parva, Nothorthis penetrabilis, Panderina lata, Dianulites helenae, Revalotrypa gibbosa (Пушкин, 1978б), а в скв. Таученис - Dideroceras popovkense, указывающие на волховский возраст отложений.

\section{Пиворская свита}

Стратотипический разрез пиворской свиты, вскрытый при бурении скв. Твярячюс (глубина 330,0-325 м), содержит следующие отложения (снизу вверх):

1) $0,18 \mathrm{~m}$ - мергель темно-серый с большим количеством (до $50 \%$ ) псевдооолитов (диаметром менее 2 мм) - в основном лимонитизированных слепок микрогастропод, реже остракод и члеников стебля иглокожих. Содержание нерастворимого остатка $55 ; \mathrm{CaO} 17 ; \mathrm{MgO}$ $1,9 \%$. Как литосостав, так и появление Amorphognatus variabilis (рис. 2), а также и соответствующей ассоциации граптолитов, хитинозои Rhabdochitina sp., Conochitina sp., Cyathochitina sp., маркируют низы кундаского горизонта;

2) 0,4 м - известняк доломитовый серый, крупнодетритовый (более 0,5 мм), послойно биоморфный с обилием трилобитов, детрита иглокожих и т. д. В верхних слоях - с прослоями и линзами зеленоватотемносерого мергеля, мощность которых достигает 1 см, и с глауконитовыми слепками микрогастропод (до 3\%). Содержание нерастворимого остатка около 4,5; $\mathrm{CaO} 44 ; \mathrm{MgO} 5,8 \%$, опмечается обновление иглокожих;

3) 2,3 м - мергель зеленовато-серый детритистый (до 15\%), неравномерно доломитизированный с прослоями глинистого доломитизированного детритового известняка. Породы псевдооолитовые, включают лимонитизированные слепки микрогастропод, остракод и членики стебля иглокожих. В низах преобладают гастроподы, в верхах иглокожие. Мощность слоев мергеля $2-6$, известняка $3-5$ см. Слоистость волнисто-полосчатая. В мергелях содержание нерастворимого остатка 46; $\mathrm{CaO} 31,2 ; \mathrm{MgO} 2,3 \%$. В макрофауне трилобиты, состав иглокожих обновляется;

4) 2,1 м - известняк серый доломитизированный с прослоями мергеля, крупнодетритовый, включает псевдооолиты (до 50\%) - многочисленные лимонитизированные слепки остракод и членики стебля иглокожих. Наблюдается детрит хитинового или фосфатного составов. Слоистость волнистая, реже волнисто-полосчатая. Послойно отмечены ходы илоедов и остатки трилобитов. В известняках содержание нерастворимого остатка 11,$1 ; \mathrm{CaO} 43 ; \operatorname{MgO} 3,0 \%$. Отмечается обновление всех групп микрофауны; в верхней части слоя среди конодонтов многочисленны аморфогнатусы. 


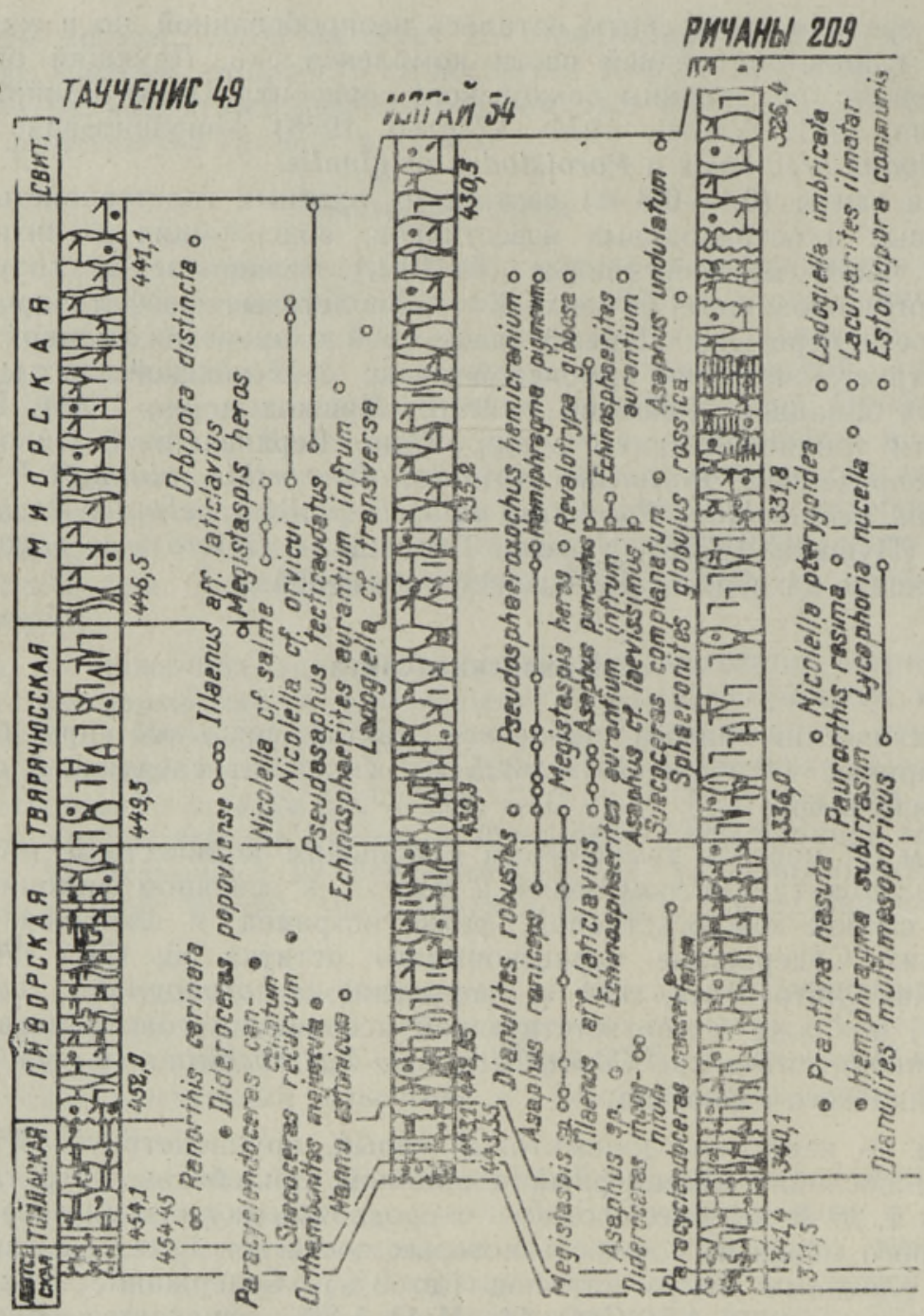

Рис. 3. Схема сопоставления отложений скв. Таученис 49, Илгай 54, Ричаны 209. Условные обозначения см. на рис. 2.

Во вторых слоях скважин Юго-Восточной Прибалтики вместе с зернами глауконита кое-где были пиритизированные, в оолитовых слоях - лимонитизированные поверхности перерыва, в подошве свиты местами глауконитовый песчаник и обломки пиритизированного известняка тойлаской свиты. В пиворской свите кундаского возраста кроме конодонтов определены эндоцератиды, в верхах свиты Asaphus raniceps (рис. 3). Остракоды Tallinnellina primaria, найденные в средней части свиты, неизвестны ранее для кундаского горизонта, но очень сходны с $T$. divelata (Сарв, 1963), многочисленными в низах кундаского горизонта, а также ниже и выше по разрезу.

\section{Твярячюсская свита}

Стратотипический разрез твярячюсской свиты вскрыт при бурении скв. Твярячюс на глубине $325-321,9$ м и представляет собой (снизу вверх): 
1) 1,1 м - мергель серый с маломощными прослоями и стяжениями серого (доломитизированного мелкокристаллического) крупнодетритового известняка, содержание которого не превышает $10 \%$ общей мощности слоя; в верхней части - псевдооолитовый $(35-50 \%)$, с лимонитизированными члениками стебля иглокожих. Содержание нерастворимото остатка в мергеле 53,6 ; $\mathrm{CaO} 17,5 ; \mathrm{MgO} 3,1 \%$;

2) 2,0 м - мергель, тлинистый мергель и глину - зеленовато-светлосерые детритистые с редкими маломощными $(1,5-3$ см) прослоями и стяжениями серого глинистого крупнодетритового (брахиоподового, послойно иглокожего) известняка; содержание нерастворимого остатка 33,$2 ; \mathrm{CaO} 30,6 \%$. Здесь фауна беднее, чем в подстилающих породах.

Характер разреза сохраняется по всему рассматриваемому району: в южной части увеличиваются содержание детрита и карбонатность пород. Мощность свиты $3,2-4,2$ м. Нижняя граница свиты проводится с учетом преобладания мергелей в разрезе. Фауна и литосостав нижней и верхней частей свиты несколько различаются; облик кундаского торизонта сохраняется. Кроме указанных форм (рис. 2, 3), в свите (скв. Ричаны, Видзы, Верхнедвинск, Оцковичи и др.) имеются: Iru concava, Ladogiella imbicata, Hemiphragma sp., Orbipora acanthopora.

\section{Миорская свита}

В стратотипическом разрезе (скв. Твярячюс) миорская свита вскрыта на глубине $321,9-317,2$ м. Снизу вверх следуют:

1) 1,1 м - мергель зеленовато-серый с прослоями желтовато-серого, крупнодетритового (до $60 \%$ ), псевдооолитистого (до $15 \%$ ) известняка.

2) 1,0 м - известняк светло-серый с тонкими (1-2 cм, реже до $5 \mathrm{~cm})$ прослоями мергеля, местами желтовато-серый за счет пятнистой доломитизации и скоплений псевдооолитов (лимонитизированных слепок остракод и члеников стебля иглокожих). Известняки среднеслоистые, слабо комковатые, послойно крепкие, плотные. Мергели зеленоватосерые в виде тонких $(0,1-0,5 \mathrm{~cm})$ линзовидно-волнистых, реже волнисто-полосчатых прослоев мощностью до 5 см. Отмечаются частые неровные поверхности перерыва, сильно пропитанные гидроокислами железа, особенно четкие в основании и в середине комплекса; выше - породы более плотные. Поверхность в середине аналогична пограничной поверхности перерыва между кундаским и азериским горизонтами в стратотипическом районе последних. Выше фауна конодонтов заметно беднеет. В кровле слоя - неровная фосфатная поверхность перерыва;

3) 0,8 м - известняк серый и буровато-серый с редкими красными пятнами, крепкий, плотный, детритово-псевдооолитистый, с лимонитизированными слепками остракод, реже с члениками стебля иглокожих. Содержание нерастворимого остатка 4,2 ; $\mathrm{CaO} 48,1 ; \mathrm{MgO} 3,1 \%$;

4) 0,4 м - доломитизированный мелкокристаллический, тонко- и ореднеслоистый известняк вперемешку с тонкими слоями мертеля. Породы богаты фрапментами иглокожих, остракоды наблюдаются реже;

5) 1,4 м - серый известняк с прослоями мергеля. Преобладают крепкие детритовые известняки с лимонитизированным детритом в нижней части. Мощность прослоев известняка $1-3$, реже до 5 см, содержание нерастворимого остатка - 18,3; $\mathrm{CaO} 41,2 ; \mathrm{MgO} 16,1 \%$. Прослои мергеля зеленовато-серые, детритовые, тонкие $(0,5-4$ см), невыдержан- 
ные. Слоистость волнистая и волнисто-полосчатая. Характерны темносерые извилистые (широкие глинистые) ходы илоедов, в кровле слоя лимонитизированная поверхность перерыва.

В верхней части кровли следуют: $(3,0+\mathrm{m})$ известняки серые плотные, слабо комковатые, от тонко- до среднеслоистых, с прослоями мергеля $(<1$ см, реже до $4 \mathrm{~cm})$; в середине фосфатная поверхность перерыва.

Состав миорской свиты устойчив по всему расоматриваемому району. В юго-восточной части района породы доломитизированы; коегде наблюдаются лимонитизированные поверхности перерыва. В средней части разреза поверхности пиритизированные; местами свита выклинивается (скв. Смолярная 035, Вилькишкяй 68).

Возраст миорской свиты - от позднекундаского до ласнамягиского включительно. В разрезе Твярячюс к кундаскому горизонту относится нижняя $(1,6$ м $)$, к азерискому - средняя часть $(1,7$ м) свиты. Возраст свиты в верхней части этой скважины не определен, но в других скважинах установлены формы азериского и ласнамягиского возрастов (рис. 3). Миорская свита находится в корреляции с пестроцветной рокишкской свитой Западной Литвы.

Все рассмотренные в данной статье свиты кундаското и азериского горизонтов (по расположению в разрезе, общему возрасту и составу) имеют аналоги в стратотипическом районе соответствующих горизонтов (Орвику, 1960; Решения ..., 1978). Пиворская свита - аналог низов силлаоруской свиты раннекундаского возраста. Она богата содержанием Tallinnellina divelata; в верхах свиты имеются также Asaphus raniceps и другие формы среднего подгоризонта кундаского горизонта. О кундаском возрасте низов свиты говорит наличие Amorphognatus variabilis, а также эндоцератоидей (рис. 2,3 ).

Средняя и верхняя части твярячюсской свиты соответствуют безоолитовой сероцветной лообуской (середина кундаского торизонта), но отличаются от нее значительной глинистостью. Миорская свита аналогична кандлеской. Обе имеют четкую лимонитизированную поверхность перерыва, маркирующую границу кундаского и азериского горизонтов; выше этой поверхности ппявляются формы, характерные среднему ордовику (рис. 3).

\section{Л И ТЕ Р А Т У Р А}

Buйра B. Распространение конодонтов в нижнеордовикских отложениях разреза Сухкрумяги (г. Таллин). - Изв. АН ЭССР. Физ. Мат., 1966, 15, 150-155.

Лашков Е. М., Пашкевичюс Н. Ю., Сидаравичене Н. В. Литостратиграфия ордовикских отложений Среднелитовского прогиба. - В кн.: Древнепалеозойские отложения Прибалтики. Таллин, 1983, $77-93$.

Мrги C., Вийра B. Распространение конодонтов и беззамковых брахиопод в цератопигевом и латорпском горизонтах Северной Эстонин. - Изв. АН ЭССР Хим. Геол., 25, 1976, 312-318.

Орвику К. О литостратиграфии тойлаского и кундаского горизонтов в Эстонии. В кн.: Тезисы докладов научной сессии, посвященной 50 годовщине со дня смерти академика Ф. Б. Шмидта. Таллин, 1958, 30-34.

Орвику K. К. Литофащиальные особенности ордовикских горизонтов волхов ( $\left.\mathrm{B}_{11}\right)$, кунда $\left(\mathrm{B}_{I I I}\right)$ и азери $\left(\mathrm{C}_{\mathrm{I}} \mathrm{a}\right)$ в Северной части Эстонской ССР. - Международный Геологический конгресс, ХХІ сессия. Докл. сов. геол., 1960, 71-82.

Пашкевичюс И. Ю. Ордовик Литвы. - В кн.: Сборник статей для 21 сессии Международного геологического конгресса. Вильнюс, 1960, 60-64.

Пашкевичюс Н. Ю. Биостратиграфия, корреляция и граптолиты ордовикских и силурийских отложений Южной Прибалтики. Автореф. док. дис. Внльнюс, 1973.

Пушкин В. Н. Биостратиграфическая характеристнка ордовика в разрезе скважины Видзы (Витебская обл. БССР). - В кн.: Современные проблемы геологии БССР. Минск, 1978а, 15-22.

Пуикин В. Н. Ордовикская система. - В кн.: Стратиграфические и палеонтологические исследования в Белоруссии. Минск, 1978б, 124-126. 
Пушкин В. И., Зиновенко Т. В., Пискун Л. В., Ропот В. Ф. Стратиграфическая схема ордовикских отложений Белоруссин. - В кн.: Материалы по стратиграфии Белоруссии. Минск, 1981, 34-41.

Решения Межведомственного регионального стратиграфического совещания по разработке унифицированных стратиграфических схем Прибалтикн. Л., 1978.

Рыььмусокс A.K. Биостратиграфическое расчленение ордовика Эстонской ССР. Таллин, 1956, 9-29.

Саладжюс В. Ю. О распределении фауны моллюсков в ордовике и силуре Южной Прибалтики. - В кн.: Палеонтология и стратиграфия Прибалтики и Белоруссии, II. Вильнюс, $1970,345-352$.

Сарв Л. Новые остракоды Прибалтики, ХІІІ. Таллин, 1963, 161-188.

Сидаравичене $H$ : Ордовикские остракоды Южной Прибалтики и их стратиграфическое значение. Автореф. канд. дис. Вильнюс, 1972.

Lindström, M. Lower Ordovician conodonts of Europe. - Geol. Soc. Am. Mem., 1971, $127,21-61$

Löfgren, A, Arenigian and Llanvirnian conodonts from Jämtland, northern Sweden. In: Fossils and Strata. Oslo, 1978, 129.

Wamel, W. J. Conodont biostratigraphy of the Upper Cambrian and Lower Ordovician of north-western Öland, south-eastern Sweden. - Utrecht Micropaleontological Bulletins, 1974, 10, 122.

$\begin{array}{cc}\text { Научно-исследовательский } & \text { Поступила в редакцию } \\ \text { геологоразведочный институт } & \text { 1/VII } 1982 \\ \text { Литовской ССР } & \end{array}$

\section{Ннститут геологии \\ Академии наук Эстонской ССР}

Вильнюсский ордена Трудового Красного

Знамени государственный университет

им. В. Капсукаса

Научно-исследовательский

геологоразведочный институт

Белорусской ССР

E. LASKOV, Silvi MAGI, J. PASKEVICIUS, V. PUSKIN

\section{IDA-LEEDU JA LOODE-VALGEVENE ARENIGI JA LLANVIRNI (LATORPI-LASNAMÄE LADEMED) STRATIGRAAFIA}

Artiklis on antud Kagu-Baltikumi alamordoviitsiumi Arenigi ja Llanvirni madalaveelise fatsiaalvööndi kihtide litoloogiline ja paleontoloogiline iseloomustus (põhiliselt Tveriačiuse puuraugu materjalide pōhjal). Kihtide vanuse määramisel on lähtutud litostratigraafilisest rööbistamisest. Põhja-Eesti stratotüüpsete läbilōigetega ja konodontide analüüsist. Kagu-Baltikumi Arenigi ja Llanvirni kihid erinevad Põhja-Eesti vastavatest kihtidest pōhiliselt suurema savikuse poolest. Alumist ja ülemist ooliidikihti iseloomustavad pseudo-ooliidid - limonitiseerunud ostrakoodid, mikrogastropoodide valatised ja okasnahksete varrelülid. Kihtide omavaheliste erinevuste pōhjal on eristatud uued kohalikud stratigraafilised ühikud Pivori, Tverečiuse ja Miori kihistu (üldjoontes Sillaoru, Loobu ja Kandle kihistu bio- ja litostratigraafilised analoogid). Nende all lasuvad Toila ja Leetse kihistu (analoogiliselt Pōhja-Eesti vastavatele kihistutele).

\section{E. LASHKOV, Silvi MĂGI, J. PASKEVICIUS, V. PUSHKIN}

\section{STRATIGRAPHY OF THE ARENIG AND LLANVIRN (LATORP-LASNAMÄGI STAGES) OF EAST-LITHUANIA AND NORTH-WEST BYELORUSSIA}

In this paper a description is given of the new (Pivorai, Tverečius and Miory) Formations mainly in the stratotypical, the Tverečius borehole (Lithuania). These formations are analogues of the Sillaoru, Loobu and Kandle Formations (in the Kunda, Aseri and Lasnamägi Stages) of North Estonia. They differ from the latter by a more notable content of clay. In the South-Eastern Baltic the equivalents to the classic «lower and upper oolitic beds» are actually pseudo-oolitic; they include many limonitjic fragments of echinoderms and limonitic casts of microgastropods and ostracods. 